\title{
Response Mechanism of Sediment Organic Matter of Plateau Lakes in Cold and Arid Regions to Climate Change: a Case Study of Hulun Lake, China
}

\section{Wenwen Wang ( $\triangle$ wangwenwen-5720088@163.com )}

North China Electric Power University - Beijing Campus: North China Electric Power University https://orcid.org/0000-0002-6951-8292

Li Zhao

Chinese Research Academy of Environmental Sciences

Wei Li

North China Electric Power University - Beijing Campus: North China Electric Power University Junyi Chen

Chinese Research Academy of Environmental Sciences

Shuhang Wang

Chinese Research Academy of Environmental Sciences

\section{Research Article}

Keywords: cold and arid area, Hulun Lake, sediment organic matter, climate change, sedimentary evolution, source

Posted Date: December 29th, 2021

DOI: https://doi.org/10.21203/rs.3.rs-1041618/v1

License: (c) (1) This work is licensed under a Creative Commons Attribution 4.0 International License. Read Full License 


\section{Abstract}

Lake organic matter is one of the important forms of terrestrial carbon, and its sedimentary evolution is affected by many factors such as climate and source. However, few studies have been conducted on the bidirectional feedback mechanism between the sedimentary evolution of organic matter and climate change in cold and arid lakes. Historical variations of the sediment organic matter (SOM) and source construction of Hulun Lake, a typical lake in the cold and arid region of China, were studied by multiple methods. The interactions and feedback mechanisms between the sedimentary evolution, climate change, and source construction change were also discussed. Overall, the characteristic indexes of the SOM showed obvious and uniform characteristics of periodical changes. The indexes were relatively stable before 1920, and fluctuated from 1920 to 1979. Since the 1980s, the total organic carbon, carbon stable isotope, and fluorescence intensity of the protein-like component in the water extractable organic matter in the SOM has increased, while the carbon to nitrogen ratio decreased. The absolute dominant contribution of terrestrial source to the SOM had changed, and the relative average contribution rate of autochthonous source increased from $17.6 \%$ before 1920 to $36.9 \%$ after 2000 . The increase of temperature, strong evaporation concentration effect, and the source construction change are the important driving factors of the sedimentary evolution of organic matter in Hulun Lake.

\section{Introduction}

Organic matter exists widely in various water environments and is one of the important forms of terrestrial carbon (Imbeau et al. 2021, Zhang et al. 2021). Lake sediments are important storage sites of organic matter (Lin et al. 2021, Sobek et al. 2014). After entering the water body, organic matters from various sources settle to the bottom of the lake and become part of the sediments through a series of complex physical, chemical and biological effects. The information, including climatic conditions, primary productivity, nutrient status of the water body, and pollution sources and so on, carried by the organic matter are well recorded in the sediments with the deposition of organic matter (Lin et al. 2021, Zhao et al. 2021). The information recorded by the sediments is high-resolution and continuous. Many research results indicate that the vertical historical evolution of sediment organic matter (SOM) indicators, such as total organic carbon (TOC), carbon nitrogen ratio $(\mathrm{C} / \mathrm{N})$, and carbon stable isotope $\left({ }^{13} \mathrm{C}\right)$, can reflect the historical changes of the climate, water environment, and human activities in the lake basin (Lin et al. 2021, Sun et al. 2016, Zhang et al. 2018a).

The migration, transformation, and deposition of organic matter among different mediums in lake water environment are very complex and are affected by many factors, including of human activities and their intensity, the lake water environment, hydrological conditions, the climate environment and change of the basin, and pollution sources (Jiang et al. 2020, Razum et al. 2021). The change of climate factors, such as temperature, precipitation, and evaporation in the lake basin will change the primary productivity and the input of surface runoff, and affect the input source and the amount of organic matter input in the lake water environment, consequentially affecting the burial characteristics of organic carbon (Chen et al. 2012, Lipczynska-Kochany 2018, Liu et al. 2021). The water environment of lakes in cold and arid regions 
is sensitive to human disturbance, and environment and climate change (Jensen et al. 2020, LozanoGarcia et al. 2013, Qiang et al. 2005, Yi \&Zhang 2015). The lakes in cold and arid regions are hence ideal areas for studying the occurrence characteristics, migration, transformation, sedimentary evolution, and influencing factors of lake organic matter. In recent years, the water ecological environment of lakes in cold and arid regions has changed to a certain extent due to global climate change. Driven by climate change, summer blooms occur frequently in Hulun Lake, Qinghai Lake, Xingkai Lake, and other lakes in cold Northern China, and some lakes (such as Hulun Lake) have been erupting by alga blooms regularly in summer. Climate change leads to the change of the terrestrial and aquatic ecological environments of lakes, which leads to the change of the source construction of organic matter, and ultimately affects the occurrence characteristics and sedimentary evolution of organic matter. Therefore, studying the sedimentary evolution and source variation characteristics of organic matter in cold and arid lakes is of great significance for understanding the migration and transformation of lake carbon and the historical changes of the basin climate and the water environment.

Hulun Lake is the largest lake in Northern China and a typical lake in cold and arid regions, playing an irreplaceable role in maintaining the ecological balance of Hulun Buir Grassland and even ecological security in Northern China (Bao et al. 2021, Li et al. 2019, Liu \&Yue 2017). Few studies have been conducted on the organic matter in Hulun Lake, especially on the sedimentary evolution, source composition, and influencing factors of organic matter. The climate in the Hulun Lake basin has been gradually warming and drying in recent years (Bao et al. 2021, Chen et al. 2012). The source and occurrence characteristics of SOM are bound to change with the climate. In view of this, this study performed the following: (1) determined the depth-chronology model of the sediment cores of Hulun Lake by adopting the lead $\left({ }^{210} \mathrm{~Pb}\right)$ and cesium $\left({ }^{137} \mathrm{Cs}\right)$ isotopic dating technology; (2) analyzed the sedimentary and evolution characteristics of the characteristic indexes of $\mathrm{SOM}$, including the TOC, the $\mathrm{C} / \mathrm{N}$ ratio, $\delta^{13} \mathrm{C}$, and the protein-like component in water extractable organic matter (WEOM) in the sediment cores; (3) analyzed the historical variation of the source construction of SOM; and (4) determined the influence and feedback mechanism of the sedimentary evolution of the organic matter in Hulun Lake due to changes in climate and source construction. This study will help in the comprehensive understanding of the sedimentary evolution characteristics of organic matter in Hulun Lake and their indicative effect on the environmental changes of the basin and the ecological environment protection of Hulun Lake.

\section{Materials And Methods 2.1 Study area}

The Hulun Lake $\left(48.55^{\circ}-49.33^{\circ} \mathrm{N}, 116.97^{\circ}-117.81^{\circ} \mathrm{E}\right)$ basin, which has an area of $2.92 \times 10^{5} \mathrm{~km}^{2}$, is located in China and Mongolia. The length, width, circumference, and average water depth of Hulun Lake are $93 \mathrm{~km}, 32 \mathrm{~km}, 447 \mathrm{~km}$, and $5.7 \mathrm{~m}$, respectively (Li et al. 2019).

The average temperature of the Hulun Lake basin is $-0.2{ }^{\circ} \mathrm{C}$, with an ice-forming period of six months (Xiao et al. 2020). Evaporation is large and precipitation is small in the basin, and precipitation is mainly 
concentrated in June to September, accounting for $80-86 \%$ of the annual average precipitation. Grassland is the main land use type, and the natural grassland area is $20132.69 \mathrm{~km}^{2}$, accounting for $81 \%$ of the total basin area (Wang et al. 2021a).

\subsection{Sample collection and treatment}

Two sediment cores (HLH 16 and HLH 26) with a length of $65 \mathrm{~cm}$ were collected in July 2019 using a Beeker cylindrical sampler (NL, $\Phi=12 \mathrm{~cm}$, Eijkelkamp, 04.23; SA, the Netherlands). The sampling sites are shown in Fig. 1. The core samples were stratified at the site at an equal spacing of $1 \mathrm{~cm}$. The stratified sediment samples were stored in clean ziplocked bags in an incubator at $4{ }^{\circ} \mathrm{C}$ and immediately transported back to the laboratory.

\subsection{Experimental methods}

\subsection{1 $\mathrm{C} / \mathrm{N}$}

The inorganic carbon in the sediment samples were removed by pretreatment with $\mathrm{HCl}(3 \mathrm{~mol} / \mathrm{L})$, and inorganic nitrogen was removed by pretreatment with $\mathrm{KCl}(2 \mathrm{~mol} / \mathrm{L})$ and $\mathrm{HCl}(0.5 \mathrm{~mol} / \mathrm{L})$ (Zhang et al. $2018 \mathrm{~b})$. The pretreated samples were then freeze-dried and sieved using a 100 -mesh $(0.15 \mathrm{~mm})$ nylon sieve. The TOC and totol organic nitrogen (TON) were analyzed using the Elementar (Elementar vario MACRO cube, Elementar Analysensysteme $\mathrm{GmbH}$, Germany). C/N refers to the TOC to TON ratio.

\subsubsection{Extraction and spectrum scanning of WEOM}

A sediment sample $(1 \mathrm{~g})$ and $50 \mathrm{~mL}$ of ultrapure water were added in a $100 \mathrm{~mL}$ centrifuge tube. The tube was oscillated in a water bath at $25^{\circ} \mathrm{C}$ for $1 \mathrm{~h}$ and then centrifuged. The supernatant was filtered with a $0.45 \mu \mathrm{m}$ membrane to obtain the WEOM extract. The full wavelength $(200-700 \mathrm{~nm})$ and threedimensional fluorescence excitation emission matrix (EEM) fluorescence spectrum of the WEOM were respectively scanned using an ultraviolet-visible spectrophotometer (D5000, Hach, USA) and a fluorescence analyzer (Hitachi, F7000, Japan) respectively according to the method of Wang et al. ( 2018). Ultrapure water was scanned synchronously for the baseline correction. The calibration methods of EEM data were calibrated and the fluorescence components were determined through the PARAFAC technology according to the methods of Wang et al. (2018).

The humification index (HIX) is the ratio of the peak area in the $\lambda_{\mathrm{Em}}$ range of $435-480 \mathrm{~nm}$ to the peak area in the $\lambda_{\mathrm{Em}}$ range of $300-345 \mathrm{~nm}$ at the $\lambda_{\mathrm{Ex}}$ value of $255 \mathrm{~nm}$ (Huguet et al. 2009).

\subsection{3 $\delta^{13} \mathrm{C}$}

The sediment sample pretreated with $\mathrm{HCl}(3 \mathrm{~mol} / \mathrm{L})$ and $2-3 \mathrm{~g}$ of $\mathrm{CuO}$ wire were placed into a quartz tube (preheated to $850^{\circ} \mathrm{C}$ for $2 \mathrm{~h}$ ). The tube was then welded, sealed in a high-vacuum system, and burned $\left(850^{\circ} \mathrm{C}, 5 \mathrm{~h}\right.$ ), and then the $\mathrm{CO}_{2}$ was purified in a vacuum system (Liang et al. 2014). The $\delta^{13} \mathrm{C}$ was analyzed using an isotope mass spectrometer (MAT252, Finnigan Mat, Germany). The Pee Dee Belemnite 
of Cretaceous in South Carolina, USA was used as the standard substance, with an analytical error of $0.2 \%$. The $\delta^{13} \mathrm{C}$ values were calculated using Eq. (1):

$\delta^{13} \mathrm{C}=\left(\frac{R_{t}}{R_{s}}-1\right) \times 100 \% 60$

where $R_{\mathrm{t}}$ is the ${ }^{13} \mathrm{C}$ to ${ }^{12} \mathrm{C}$ natural abundance ratio of the sample, and $R_{\mathrm{s}}$ is that of the standard substance.

\subsubsection{Relative contribution of organic matter sources}

The relative contribution rates of the terrestrial $\left(P_{\mathrm{T}}\right)$ and autochthonous $\left(P_{\mathrm{A}}\right)$ sources for SOM on the basis of $\mathrm{C} / \mathrm{N}$ were calculated using a binary model (Qian et al. 1997). $P_{\mathrm{T}}$ and $P_{\mathrm{A}}$ based on $\delta^{13} \mathrm{C}$ were calculated using Eqs. (2) and (3) (Koszelnik et al. 2018):

$$
\begin{gathered}
\delta^{13} \mathrm{C}=\delta^{13} C_{\mathrm{T}} \times P_{\mathrm{T}}+\delta^{13} C_{\mathrm{A}} \times P_{\mathrm{A}} \text {, and } \\
P_{\mathrm{T}}+P_{\mathrm{A}}=1 .
\end{gathered}
$$

$\delta^{13} C_{T}$ is the $\delta^{13} \mathrm{C}$ value of the terrestrial organic matters in the sample, and $\delta^{13} C_{A}$ is that of the autochthonous organic matters in sample.

\subsubsection{Chronology calculation of sediments}

Radionuclide ${ }^{210} \mathrm{~Pb}$ and ${ }^{137} \mathrm{Cs}$ have been widely used in the chronology determination of sediments in water bodies (Abbasi 2019, Kumar et al. 2016, Nie et al. 2016). In practice, the two dating methods are usually combined and verify each other to improve the accuracy and reliability of dating results. $A$ composite model based on the combination of ${ }^{210} \mathrm{~Pb}$ and ${ }^{137} \mathrm{Cs}$ was used to calculate the sediment chronology of Hulun Lake. The sediment age $\left(T_{\mathrm{z}}\right)$, sedimentation rate $\left(R_{\mathrm{z}}\right)$, and organic carbon burial rate (OCBR) in the sediments were calculated according to the method of Zhang et al. (2018a).

\subsection{Statistical analysis}

All the indexes were analyzed in parallel three times, and the test results were expressed as the average value of the three parallel analyses with the error range of the three analysis results $<5 \%$. The Pearson correlation coefficient method was used for correlation analysis in the SPSS 17.0 software. Excel 2010, Origin 8.0, SPSS 17.0, ArcGIS 10.2, Matlab 7.0, and Surfer 14.0 were used for the statistical inspection, analysis and plotting of experimental data.

\section{Results And Discussion}

\subsection{Depth-chronology model of the sediment cores of Lake Hulun}


The excess ${ }^{210} \mathrm{~Pb}\left({ }^{210} \mathrm{~Pb}\right.$ ex $)$ in the HLH16 and HLH26 cores in Hulun Lake ranged from $8.6 \mathrm{~Bq} / \mathrm{kg}$ to 520.9 $\mathrm{Bq} / \mathrm{kg}$ and $11.0 \mathrm{~Bq} / \mathrm{kg}$ to $334.2 \mathrm{~Bq} / \mathrm{kg}$, with the mean values of 165.6 and $120.5 \mathrm{~Bq} / \mathrm{kg}$, respectively. The ${ }^{210} \mathrm{~Pb}_{\mathrm{ex}}$ values in the two cores all showed serrated distributions in the vertical direction. The distribution decreased gradually and then stabilized with the increase of the sediment depth (Fig. 2).

The ${ }^{137} \mathrm{Cs}$ values in the $\mathrm{HLH} 16$ and $\mathrm{HLH} 26$ cores were in $0-61.7 \mathrm{~Bq} / \mathrm{kg}$ and $0-48.9 \mathrm{~Bq} / \mathrm{kg}$ ranges, with mean values of 13.8 and $13.7 \mathrm{~Bq} / \mathrm{kg}$, respectively. The vertical distributions of ${ }^{137} \mathrm{Cs}$ in the sediment cores presented typical single-peak distribution characteristics, which are similar to the results of previous reaearch on Hulun Lake and other lakes (Fig. 3). According to the sedimentary characteristics of ${ }^{137} \mathrm{Cs}$ in the northern hemisphere, the maximum peak of the ${ }^{137} \mathrm{Cs}$ distribution curve corresponds to the peak of the nuclear explosion test in 1963, which can be used as an important time scale for the sediment dating of Hulun Lake.

The corresponding relationship between the sediment core depth and the chronological sequence of Hulun Lake was shown in Fig. 4. The average sedimentation rates of the HLH16 and HLH26 cores since 1950 were 0.44 and $0.61 \mathrm{~cm} / \mathrm{a}$, respectively. The sedimentation rate of the HLH26 core in the middle of the lake was higher than that of the HLH16 core. This result may be attributed to the relatively stable hydrodynamic conditions in the middle of the lake, which is more conducive to the formation of sediment. The sedimentation rate of the HLH26 core was similar to the study results of Gao $(0.72 \mathrm{~cm} / \mathrm{a})$ (Gao 2017) and Zhang et al. (0.58 cm/a) (Zhang et al. 2018a), indicating that the dating results are relatively accurate.

\subsection{Sedimentary evolution characteristics of organic matter in Hulun Lake}

\subsubsection{TOC}

The TOC contents in the HLH16 and HLH26 cores were in the 27.9-43.1 and 30.4-49.0 g/ kg ranges, with mean values of 32.6 and $36.7 \mathrm{~g} / \mathrm{kg}$, respectively. The average OCBR values in the HLH16 and HLH26 cores were 1.60 and $1.83 \mathrm{~g} /\left(\mathrm{m}^{2} \cdot \mathrm{a}\right)$, respectively. The TOC contents in the sediment cores in Hulun Lake have shown a fluctuant and increasing trend in recent years, and the annual TOC variation can be roughly divided into four stages (Fig. 5).

Before 1920, the TOC contents in the sediment cores were relatively stable and the OCBC values were low, with mean values of 0.85 and $0.37 \mathrm{~g} /\left(\mathrm{m}^{2} \cdot \mathrm{a}\right)$ in the HLH16 and HLH26 cores, respectively. Years 1920 to 1979 can be considered as the transition period of organic matter sedimentary evolution in Hulun Lake. The TOC contents in the HLH16 and HLH26 cores varied within $27.9-37.6$ and $30.4-41.4 \mathrm{~g} / \mathrm{kg}$, and the average OCBR values were 2.37 and 2.77 , respectively. Since 1980, the TOC content in the sediment cores has shown an obviously increasing trend. From 1980 to 1999, the TOC contents in HLH16 and HLH26 ranged from $28.5 \mathrm{~g} / \mathrm{kg}$ to $35.7 \mathrm{~g} / \mathrm{kg}$ and $36.3 \mathrm{~g} / \mathrm{kg}$ to $40.1 \mathrm{~g} / \mathrm{kg}$, with TOC averages of 32.8 and $37.8 \mathrm{~g} / \mathrm{kg}$ and OCBR averages of 1.59 and $2.68 \mathrm{~g} /\left(\mathrm{m}^{2} \cdot \mathrm{a}\right)$, respectively. Since 2000 , the TOC contents have increased 
further and remained at a high level in recent years. The TOC contents in HLH16 and HLH26 varied from $32.1-43.1$ and $35.4-49.0 \mathrm{~g} / \mathrm{kg}$, and the average values increased to 36.5 and $41.6 \mathrm{~g} / \mathrm{kg}$, respectively. The OCBR values increased to 1.74 and $3.30 \mathrm{~g} /\left(\mathrm{m}^{2} \cdot \mathrm{a}\right)$, respectively.

The variation trend of the TOC contents in the sediment cores in Hulun Lake over the years indicates that the TOC and the OCBR have an overall increasing trend. The TOC increased significantly after 1980, especially since 2000 , and the OCBR reached its maximum value, indicating that the climate, water and hydrological conditions of Hulun Lake may have changed significantly during this period.

\subsection{2 $\mathrm{C} / \mathrm{N}$}

The $\mathrm{C} / \mathrm{N}$ values in the HLH16 and HLH26 cores in Hulun Lake fluctuated within 11.9-19.7 and 8.6-16.1, with mean values of 15.6 and 12.7, respectively. The $\mathrm{C} / \mathrm{N}$ in the sediment cores in Hulun Lake has shown a fluctuant and decreasing trend in recent years (Fig. 6).

Similar to the variation characteristics of the TOC content over the years, the variation of $\mathrm{C} / \mathrm{N}$ could be also roughly divided into four stages. Before 1920 , the $\mathrm{C} / \mathrm{N}$ in the sediment cores was relatively stable, and the $\mathrm{C} / \mathrm{N}$ values of $\mathrm{HLH} 16$ and $\mathrm{HLH} 26$ ranged from 14.8 to 18.8 and 12.8 to 14.3 , with averages of 16.7 and 13.6, respectively. From 1920 to 1979 , the C/N values in the sediment cores fluctuated greatly, and the $\mathrm{C} / \mathrm{N}$ values of the HLH16 and HLH26 cores varied from 11.9 to 19.7 and 11.8 to 16.1 , with mean values of 15.6 and 13.6, respectively. Since 1980, C/N has shown an obvious decreasing trend. In 19801999 , the $\mathrm{C} / \mathrm{N}$ values of the HLH16 and HLH26 cores ranged from 13.5 to 16.7 and 11.0 to 13.2 , with the averages of 15.6 and 12.4, respectively. From 2000 to 2019, the $\mathrm{C} / \mathrm{N}$ value decreased further, and the $\mathrm{C} / \mathrm{N}$ values of the HLH16 and HLH26 cores ranged from 12.9 to 14.7 and 8.6 to 10.7, with averages of 13.8 and 10.2, respectively, reaching the lowest average values in recent years.

\subsection{3 $\delta^{13} \mathrm{C}$}

The $\delta^{13} \mathrm{C}$ in the sediment cores of Hulun Lake has shown an overall increasing trend in recent years, and experienced four stages, namely, relative stability, fluctuation, gradual increase, and rapid increase successively (Fig. 7). Before $1920, \delta^{13} \mathrm{C}$ was relatively stable, and the values in the HLH16 and HLH26 cores ranged from $-27.63 \%$ o to $-27.24 \%$ ond $-27.42 \%$ o to $-26.92 \%$, with average values of $-27.40 \%$ ond $-27.20 \%$, respectively. In $1920-979$, the $\delta^{13} \mathrm{C}$ in the $\mathrm{HLH} 16$ and $\mathrm{HLH} 26$ cores fluctuated from $-27.64 \%$ o to $-27.15 \%$ ond $-27.56 \%$ o to $-26.92 \%$, with mean values of $27.46 \%$ ond $-27.23 \%$ o, respectively. From 1980 to $1999, \delta^{13} \mathrm{C}$ showed an obvious and stable increasing trend, and the mean values for the HLH16 and $\mathrm{HLH} 26$ cores reached to $-27.39 \%$ and $-26.99 \%$, respectively. From 2000 to 2019 , the $\delta^{13} \mathrm{C}$ values of HLH16 and $\mathrm{HLH} 26$ ranged from $-26.94 \%$ o to $-26.40 \%$ ond $-26.60 \%$ o to $-26.17 \%$, with average values of $-26.62 \%$ ond $-26.34 \%$, respectively, reaching the highest level in recent years.

The isotopic signal of organic matter in sediments may be affected by the preferential degradation of protein-like organic matter after being buried in sediments. In general, the $\delta^{13} \mathrm{C}$ values in sediment cores should show a decreasing trend from the bottom to the top if they are influenced by the early degradation 
of organic matter (Sun et al. 2016). However, the vertical distribution of $\delta^{13} \mathrm{C}$ in the Hulun Lake sediment cores investigated in this study does not show this trend, so the influence of the early degradation of organic matter on $\delta^{13} \mathrm{C}$ can be ignored. The influence of selective diagenesis on stable isotopes is generally less than $2 \%$ (Meyers 1997) and can also be ignored in this study. Therefore, it can be concluded that the $\delta^{13} \mathrm{C}$ in the sediment cores of Hulun Lake was little affected by early degradation and diagenesis, and can effectively indicate the changes of source and environment.

\subsubsection{Protein-like component in WEOM}

The SOM components mainly include WEOM, humic acid (HA), fulvic acid (FA), and humin (HM) (Zhang et al. 2017). WEOM is the most easily degraded by microorganisms and has the highest bioactivity among these components (Hur et al. 2014). The WEOM in the sediment cores of Hulun Lake contained four fluorescence components, including three humic-like components and one protein-like component. The protein-like components reflect the tryptophan components generated by microbial and phytoplankton degradation and mainly come from autochthonous sources (Bai et al. 2017, Chari et al. 2013, Rochelle-Newall \&Fisher 2002). Therefore, the sedimentary evolution characteristics of protein-like components in the WEOM of sediment cores can reflect the historical changes of the source of organic matter and the water ecological environment in the lake.

The fluorescence intensity (FI) of the protein-like component in WEOM in the HLH16 and HLH26 cores varied in the ranges of $0.35-1.05$ and $0.39-1.06$ R.U., respectively, and has shown an overall increasing trend in recent years (Fig. 8). Before 1920, the FI values of the protein-like component in the HLH 16 and HLH26 cores were basically stable, with mean values of 0.39 and 0.41 R.U., respectively. In 1920-1999, the FI values of the protein-like components increased insignificantly and varied in ranges of $0.37-0.84$ and $0.39-0.66$ R.U., with mean values of 0.55 and 0.48 R.U., respectively. Since 2000, the FI values of the protein-like components in the HLH16 and HLH26 cores have shown an obviously increasing trend, with mean values of 0.97 and 0.86 R.U., respectively, which are nearly one time higher than those of before 1920. The protein-like components in the WEOM mainly came from autochthonous sources, and their FI values changed significantly around 2000 , indicating that the source construction of the SOM in Hulun Lake may have changed greatly. Therefore, the historical change of the source construction of the SOM in Hulun Lake must be analyzed further and verified.

\subsection{Historical variation of the source construction of SOM in Hulun Lake}

The main components of land plants are cellulose and lignin, so land plants have a high $\mathrm{C} / \mathrm{N}$ content. The main component of aquatic phytoplankton is protein, so the $\mathrm{C} / \mathrm{N}$ of aquatic plants is lower than that of land plants (Meyers 1994). The $\mathrm{C} / \mathrm{N}$ ratio has been widely used to determine the organic matter sources in lake sediments (Bouton et al. 2020, Carrizo et al. 2019, Pu et al. 2020). The results calculated by the binary model based on $\mathrm{C} / \mathrm{N}$ indicated that the $P_{\mathrm{T}}$ and $P_{\mathrm{A}}$ varied within $70.5-98.2 \%$ and $1.8-29.5 \%$ for the HLH16 core, and within $43.3-89.6 \%$ and $10.4-56.7 \%$ for the $\mathrm{HLH} 26$ core, respectively. $\delta^{13} \mathrm{C}$ can also be used to analysis the source of SOM. The $\delta^{13} \mathrm{C}$ values in the sediment cores in Hulun Lake ranged 
from $-27.56 \%$ o to $-26.17 \%$, with a mean value of $-27.0 \%$. The $\delta^{13} \mathrm{C}$ values of the sediments were near those of the C3 plants, aquatic plants, and terrestrial materials of Hulun Lake (Zhang et al. 2018b), indicating that the SOM in Hulun Lake was influenced by both terrestrial and autochthonous sources. The $P_{\mathrm{T}}$ and $P_{\mathrm{A}}$ values calculated by $\delta^{13} \mathrm{C}$ were within $58.5-83.4 \%$ and $16.6-41.5 \%$ for the HLH16 core, and within $53.9-81.5 \%$ and $18.5-46.1 \%$ for the HLH26 core, respectively.

The SOM in Hulun Lake generated from both terrestrial and autochthonous sources, but mainly came from terrestrial source. However, the relative contribution of the terrestrial source has shown a decreasing trend in recent years. Similar to the historical variation characteristics of other organic matter indicators, the historical changes of organic matter sources could also be roughly divided into four stages (Fig. 9). Before 1920, the source construction of SOM in Hulun Lake was relatively stable, and the terrestrial source was dominant. The mean values of $P_{\mathrm{T}}$ and $P_{\mathrm{A}}$ were $82.4 \%$ and $17.6 \%$, respectively. In 1920-1979, $P_{\mathrm{T}}$ and $P_{\mathrm{A}}$ fluctuated with mean values of $80.7 \%$ and $19.3 \%$, respectively. In $1980-1999, P_{\mathrm{T}}$ showed an obviously decreasing trend, with a mean value of $76.3 \%$. In 2000-2019, $P_{\mathrm{T}}$ decreased further and has remained ina relatively low level in recent years, and the mean value was $63.1 \%$. However, the mean value of $P_{\mathrm{A}}$ increased to $36.9 \%$, which is $19.2 \%$ more than that before 1920 .

\subsection{Driving factors of the sedimentary evolution of organic matter in Hulun Lake}

When organic matter enters the lake water from sources and is deposited at the bottom of the lake, it is affected by human activities, the climatic conditions of the basin, the hydrological conditions of the lake, and other factors. The sedimentary evolution of lake organic matter is also affected by diagenesis (Leonova et al. 2019, Melenevskii et al. 2015). Compared with marine diagenesis, the sulfate content in lacustrine environments is lower because fresh water is low in sulfur, sulphate reduction is very limited, vulcanization is difficult, and early diagenesis is relatively weak. For Hulun Lake, the SOM is mainly generated from terrestrial inputs, such as land plants (pasture). Terrestrial higher plants are more abundant than algae in aromatic compounds, such as lignin, tannin, resin, and suberin, which are very stable and have a strong resistance to bacterial decomposition and are easy to preserve in sediments (Harfmann et al. 2019). Previous results also show that the dominant component of SOM in Hulun Lake was $\mathrm{HM}$, which is difficult to degrade, and the average proportion of HM to TOC was as high as $75.1 \%$ (Wang et al. 2021b). The influence of early diagenesis on THE SOM of Hulun Lake may be relatively small and will not be discussed this time. Given its special geographical location and climate conditions, the water environment of Hulun Lake is sensitive to climate change. Some results show no significant correlation between the burial rate of organic carbon and human factors, including population, cultivated area, livestock and fish (Zhang et al. 2018a). Therefore, this study focused on the impact of climate factors on the sedimentary evolution of organic matter in Hulun Lake.

The annual mean changes of temperature, precipitation and evaporation in Hulun Lake Basin from 1951 to 2018 are shown in Fig. S3. The average annual temperature fluctuated between $-2.9^{\circ} \mathrm{C}$ and $2.7^{\circ} \mathrm{C}$. Overall, the temperature in the Hulun Lake Basin showed an increasing trend (Fig. 10a). The annual 
average precipitation and evaporation of the basin were within $137.9-590.1 \mathrm{~mm}$ and $612.3-1256.3 \mathrm{~mm}$, with mean valuez of 285.9 and $906.6 \mathrm{~mm}$, respectively. The precipitation in the basin showed a gradually decreasing trend (Fig. 10b), while the evaporation showed an increasing trend (Fig. 10c). The climate in the Hulun Lake basin has been warming and drying in recent years.

The correlation relationships between climate factors (temperature, precipitation, evaporation) and SOM related indexes $\left(\mathrm{TOC}, \mathrm{C} / \mathrm{N}, \delta^{13} \mathrm{C}, \mathrm{Fl}\right.$ of protein-like components of WEOM, $P_{\mathrm{A}}$ ) are shown in Table 1. The correlation between SOM related indexes and temperature is the best, showing significant correlation $(P<$ $0.01)$, followed by evaporation. The relatively poor correlation between precipitation and the organic matter related indexes may be due to the fact that the evaporation in the Hulun Lake basin is much greater than the precipitation, and the strong evaporation effect is one of the important reasons for the reduction of water volume and level in Hulun Lake in recent years (Li et al. 2019, Liu \&Yue 2017). Therefore, the effect of evaporation on the occurrence and sedimentary evolution of organic matter in Hulun Lake may be more obvious than that of precipitation.

Table 1

Correlation relationships between climate factors and SOM related indexes of Hulun Lake

\begin{tabular}{|llll|}
\hline SOM related indexes & Temperature & Precipitation & Evaporation \\
\hline TOC & $0.420^{\star *}$ & -0.096 & $0.357^{\star}$ \\
\hline C/N & $-0.694^{\star *}$ & 0.213 & $-0.528^{\star \star}$ \\
\hline$\delta^{13} \mathrm{C}$ & $0.754^{\star *}$ & $-0.331^{*}$ & $0.595^{\star \star}$ \\
\hline Fl of protein-like components of WEOM & $0.431^{\star *}$ & -0.261 & $0.597^{\star \star}$ \\
\hline$P_{\mathrm{A}}$ & $0.707^{\star *}$ & -0.269 & $0.586^{\star \star}$ \\
\hline * significantly correlated at 0.05 level, ** significantly correlated at 0.01 level. \\
\hline
\end{tabular}

Temperature can directly affect the biomass, microbial quantity, and activity of land and water in lake basins, change the source construction of lake organic matter, and further affect the content and composition of organic matter and the migration and transformation of organic matter at the sedimentwater interface, which is of great significance to the sedimentary evolution of organic matter (Dadi et al. 2016, Luff \&Moll 2004). Hulun Lake is located in the Hulun Buir steppe, and the vast steppe provides many terrestrial organic matters for Hulun Lake. Meanwhile, due to the low temperature and long ice period in the basin, the growth of aquatic algae is greatly restricted, and the aquatic biomass of the lake is small, resulting in the small contribution of the autochthonous source to the SOM in Hulun Lake. Hence, terrestrial source has an absolute advantage over autochthonous source in the contribution to SOM in Hulun Lake. However, since the 1980 s, especially since 2000 , the basin has been exhibiting an obvious warming trend, the eutrophication in Hulun Lake has increased, the lake bloom has regularly broken out in summer, and the aquatic biomass has increased. Studies also show that the land around 
Hulun Lake has seen serious desertification, and the desertification area exceeds $100 \mathrm{~km}^{2}$ due to the significant warming and drying of climate (Zhao et al. 2008). In addition, the warm and dry climate has also led to the decrease in grassland vegetation height and grassland degradation, resulting in the relative decrease of organic matter input from terrestrial sources. Therefore, the source construction of SOM changed significantly as $P_{\mathrm{T}}$ gradually decreased and $P_{\mathrm{A}}$ gradually increased.

The change in source construction can also cause the change in SOM composition. Organic matters from terrestrial sources mainly consist of hard-degraded humic-like substances, and autochthonous organic matters mainly consist of protein-like components (Hu et al. 2019, Lu et al. 2019). WEOM is a highly active component of SOM and is closely related to microbial activities. Protein-like components mainly come from the metabolic activities or degradation of plankton and microorganisms (Chen et al. 2017, Li et al. 2020). Hence, the FI values of the protein-like component in the WEOM of the SOM in Hulun Lake show an increasing trend with the increase of $P_{\mathrm{A}}$.

The carbon isotope composition of SOM is also affected by temperature, and the change in carbon isotope composition can reflect the level of the lake's primary productivity. The $\delta^{13} \mathrm{C}$ values of land plants are more negative than that of planktonic algae. The SOM in Hulun Lake mainly came from terrestrial sources during the lower temperature period, so the $\delta^{13} \mathrm{C}$ was low. The $P_{\mathrm{A}}$ and the water primary productivity increased gradually, increasing the $\delta^{13} \mathrm{C}$. The temperature and evaporation in the basin have increased, the precipitation and lake inflow have decreased, and the surface area of Hulun Lake has shrunk rapidly since 2000 . The increase in temperature and evaporation leads to the decrease in $\mathrm{CO}_{2}$ concentration and the increase of the $\mathrm{Ca}^{2+}, \mathrm{CO}_{3}{ }^{2-}$, and $\mathrm{HCO}_{3}{ }^{-}$concentrations in water. The $\delta^{13} \mathrm{C}$ value is inversely proportional to the water $\mathrm{CO}_{2}$ supply during the synthesis of organic matter by phytoplankton, indicating that the lower the $\delta^{13} \mathrm{C}$ value is, the higher the dissolved $\mathrm{CO}_{2}$ concentration is, and vice versa (Wang et al. 2003). Hence, the $\mathrm{CO}_{2}$ concentration in the lake decreased with the increase in temperature, and the algae preferentially used $\mathrm{HCO}_{3}{ }^{-}$to increase the $\delta^{13} \mathrm{C}$ value. The evaporation concentration also resulted in enhanced isotopic fractionation in Hulun Lake, and $\delta^{13} \mathrm{C}$ was more easily enriched in the water, maintaining the $\delta^{13} \mathrm{C}$ values in the sediments remaining at a high level.

The sedimentary evolution of TOC in Hulun Lake had a good response and indicator effect on the changes in temperature, evaporation, and lake surface area. From 1951 to 1979, the climate of the basin was dry and cold, which was not conducive to the vegetation growth of the basin, and the inputs of terrestrial and autochthonous organic matters were small. Moreover, the water surface area of Hulun Lake was relatively large, and the evaporation and concentration effects were relatively weak, so the TOC content that accumulated in the sediments of this period was small. From 1980 to 1999, evaporation and water surface area fluctuated with an unobvious trend, but the TOC content also presented a fluctuating and increasing trend due to the rising air temperature, primary productivity, and organic matter inputs. The TOC contents increased significantly from 2000 to 2008. On the one hand, the increase of the TOC content in this stage was due to the increase of organic matter inputs caused by the temperature 
increase. On the other hand, the increase of the TOC content from 2000 to 2008 was due to the strong evaporation concentration effect. During this period, the evaporation increased significantly, the water level dropped sharply, and the lake area shrank seriously. Hulun Lake became a closed lake that could only enter and not exit. The strong evaporation effect led to the enrichment and concentration of organic matters in the water body, and the concentration remained at a high level, which was conducive to the settlement and accumulation of organic matters from the water body to sediments, resulting in the increase of the TOC contents in the sediments.

From 2009 to 2013, the evaporation of the basin decreased, and the water inflow and surface area of Hulun Lake increased with the operation of the river diversion project to the lake. The reduction of evaporation and the increase of water volume led to the weakening of the concentration effect, and the increase of the water level also led to the increase of the settlement distance of organic matters from the water body to the sediments and the increase of the decomposition consumption of organic matters. Therefore, the TOC contents in the sediments showed a decreasing trend in 2009 and 2013. From 2014 to 2018 , the evaporation increased, the climate was warm and dry, the primary productivity increased, and concentration effect was strong, resulting in the increasing trend of the TOC contents in the sediments.

The result of this study is consistent with previous results, that is, temperature increase will lead to the increase in SOM content. However, the temperature increase will also enhance the SOM mineralization effect. Therefore, further studies on the effects of temperature rise on the stability of the SOM of Hulun Lake and other similar lakes located in cold and arid areas should be conducted in the future, and the two-way feedback mechanism between climate change and lake carbonaceous organic matters should be further explored.

\section{Conclusion}

The sedimentary evolution of the TOC, $\mathrm{C} / \mathrm{N}$, and $\delta^{13} \mathrm{C}$ in the Hulun Lake sediment cores could be roughly divided into four periods. Before 1920, the indexes were relatively stable. From 1920 to 1979, the indexes fluctuated, and the change trend was not obvious. From 1980 to 1999 , the TOC and $\delta^{13} \mathrm{C}$ increased, while $\mathrm{C} / \mathrm{N}$ decreased. From 2000 to 2019 , the TOC and $\delta^{13} \mathrm{C}$ increased significantly, while $\mathrm{C} / \mathrm{N}$ continued to decrease and has remained at a high or low levels in recent years. After 2000, the FI of the protein-like component in WEOM increased significantly. The source construction of SOM also changed significantly. Although terrestrial input was still the main source, the contribution rate of the autochthonous source increased gradually and by approximately $20 \%$ from 2000 to 2019 compared with that before 1920 .

Since 1950, the temperature and evaporation in the Hulun Lake basin have been increasing, precipitation has been decreasing, and climate has been warming and drying. The mean annual temperature and evaporation are significantly correlated with the SOM indexes, and the historical variation trends are relatively consistent. The temperature rise and the evaporation concentration are the important driving factors of the deposition evolution of the organic matters in Hulun Lake. Temperature rise led to the increase of the primary productivity, the autochthonous contribution rate, and the FI of the protein-like

Page $12 / 24$ 
component. The strong evaporation concentration effect led to the enrichment and concentration of the organic matters in the overlying water, which led to the increase of the TOC and $\delta^{13} \mathrm{C}$ in the sediments.

\section{Declarations}

Ethics approval and consent to participate: Not applicable.

Consent for publication: Not applicable.

Availability of data and materials: The datasets used and/or analyzed in the study are available from the corresponding author upon reasonable request.

Competing interests: The authors declare no competing interest.

Funding: This work was supported by the National Key Research and Development Program of China (Program No. 2018YFE0196000).

Authors' contributions: Wenwen Wang collected and analyzed samples and was a major contributor in writing the manuscript. Li Zhao and Junyi Chen collected and analyzed the samples. Wei Li checked the quality of the paper. Shuhang Wang formulated the sampling and experimental schemes. All authors read and approved the final manuscript.

Competing interests: The authors declare no competing interest.

Acknowledgments: The authors thank the participants in this study for their time and useful insights. They also thank the support provided by the National Key Research and Development Program of China (2018YFE0196000).

\section{References}

1. Abbasi A (2019) ${ }^{210} \mathrm{~Pb}$ and ${ }^{137} \mathrm{Cs}$ based techniques for the estimation of sediment chronologies and sediment rates in the Anzali Lagoon, Caspian Sea. J Radioanal Nucl Chem 322:319-330. https://doi.org/10.1007/s10967-019-06739-8

2. Bai LL, Cao CC, Wang CL, Wang CH, Zhang H (2017) Roles of phytoplankton- and macrophytederived dissolved organic matter in sulfamethazine adsorption on goethite. Environ Pollut 230:8795. https://doi.org/10.1016/j.envpol.2017.06.032

3. Bao H, Wang GH, Yao YL, Peng ZT, Dou HS, Jiang GS (2021) Warming-driven shifts in ecological control of fish communities in a large northern Chinese lake over 66 years. Sci Total Environ 770:144722. https://doi.org/10.1016/j.scitotenv.2020.144722

4. Bouton A, Vennin E, Thomazo C, Mathieu O, Garcia F, Jaubert M, Visscher PT (2020) Microbial origin of the organic matter preserved in the Cayo Coco lagoonal network. Cuba Minerals 10:143. https://doi.org/10.3390/min10020143 
5. Carrizo D, Laura SG, Rodrigo JM, Felipe GR (2019) Discriminating sources and preservation of organic matter in surface sediments from five Antarctic lakes in the Fildes Peninsula (King George Island) by lipid biomarkers and compound-specific isotopic analysis. Sci Total Environ 672:657-668. https://doi.org/10.1016/j.scitotenv.2019.03.459

6. Chari NVHK, Keerthi S, Sarma NS, Pandi SR, Chiranjeevulu G (2013) Fluorescence and absorption characteristics of dissolved organic matterexcreted by phytoplankton species of western Bay of Bengal underaxenic laboratory condition. J Exp Mar Biol Ecol 445:148-155. https://doi.org/10.1016/j.jembe.2013.03.015

7. Chen ML, Nam S, Kim JH, Kwon YJ, Hong SW, Jung JY, Shin KH, Hur J (2017) High abundance of protein-like fluorescence in the Amerasian Basin of Arctic Ocean: Potential implication of a fall phytoplankton bloom. Sci Total Environ 599:355-363. https://doi.org/10.1016/j.scitotenv.2017.04.233

8. Chen X, Chuai X, Yang L, Zhao H (2012) Climatic warming and overgrazing induced the high concentration of organic matter in Lake Hulun, a large shallow eutrophic steppe lake in northern China. Sci Total Environ 431:332-338. https://doi.org/10.1016/j.scitotenv.2012.05.052

9. Dadi T, Friese K, Wendt-Potthoff K, Koschorreck M (2016) Benthic dissolved organic carbon fluxes in a drinking water reservoir. Limnol Oceanogr 61:445-459. https://doi.org/10.1002/Ino.10224

10. Gao HB (2017) The reconstruction of evolution processes of sedimentary environment in Lake Hulun based on high resolution sedimentary indicators. Inner Mongolia Agricultural University, Inner Mongolia

11. Harfmann J, Kurobe T, Bergamaschi B, Teh S, Hernes $P$ (2019) Plant detritus is selectively consumed by estuarine copepods and can augment their survival. Sci Rep 9:9076.

https://doi.org/10.1038/s41598-019-45503-6

12. Hu B, Wang PF, Wang C, Qian J, Bao TL, Shi Y (2019) Investigating spectroscopic and copper-binding characteristics of organic matter derived from sediments and suspended particles using EEMPARAFAC combined with two-dimensional fluorescence/FTIR correlation analyses. Chemosphere 219:45-53. https://doi.org/10.1016/j.chemosphere.2018.11.113

13. Huguet A, Vacher L, Relexans S, Saubusse S, Froidefond JM, Parlanti E (2009) Properties of fluorescent dissolved organic matter in the Gironde Estuary. Org Geochem 40:706-719. https://doi.org/10.1016/j.orggeochem.2009.03.002

14. Hur J, Lee BM, Shin KH (2014) Spectroscopic characterization of dissolved organic matter isolates from sediments and the association with phenanthrene binding affinity. Chemosphere 111:450-457. https://doi.org/10.1016/j.chemosphere.2014.04.018

15. Imbeau E, Vincent WF, Wauthy M, Cusson M, Rautio M (2021) Hidden stores of organic matter in northern lake ice: selective retention of terrestrial particles, phytoplankton and labile carbon. Journal of Geophysical Research-Biogeosciences 126(8). https://doi.org/10.1029/2020jg006233. e2020JG006233 
16. Jensen TC, Zawiska I, Oksman M, Slowinski M, Woszczyk M, Luoto TP, Tylmann W, Nevalainen L, Obremska M, Schartau AK, Walseng B (2020) Historical human impact on productivity and biodiversity in a subalpine oligotrophic lake in Scandinavia. J Paleolimnol 63:1-20. https://doi.org/10.1007/s10933-019-00100-5

17. Jiang QL, Li SD, Chen ZL, Huang CC, Wu WX, Wan HB, Hu ZJ, Han C, Zhang ZG, Yang H, Huang T (2020) Disturbance mechanisms of lacustrine organic carbon burial: Case study of Cuopu Lake, Southwest China. Sci Total Environ 746:140615. https://doi.org/10.1016/j.scitotenv.2020.140615

18. Kumar A, Hage-Hassan J, Baskaran M, Miller CJ, Selegean JP, Creech CT (2016) Multiple sediment cores from reservoirs are needed to reconstruct recent watershed changes from stable isotopes $\left(\delta^{13} \mathrm{C}\right.$ and $\delta^{15} \mathrm{~N}$ ) and $\mathrm{C} / \mathrm{N}$ ratios: case studies from the mid-western United States. J Paleolimnol 56:15-31. https://doi.org/10.1007/s10933-016-9888-0

19. Leonova GA, Maltsev AE, Melenevsky VN, Krivonogov SK, Kondratyeva LM, Bobrov VA, Suslova MY (2019) Diagenetic transformation of organic matter in sapropel sediments of small lakes (southern West Siberia and eastern Transbaikalia). Quatern Int 524:40-47. https://doi.org/10.1016/j.quaint.2019.03.011

20. Li GL, Li L, Song K, Yuan ZW, Zhu SG, Zhang J, Xie FZ (2020) Photochemical degradation characteristics of alga-sourced dissolved organic matter in Chaohu Lake, China. Water Supply 20:3083-3095. https://doi.org/10.2166/ws.2020.203

21. Li S, Chen JP, Xiang J, Pan Y, Huang ZY, Wu YL (2019) Water level changes of Hulun Lake in Inner Mongolia derived from Jason satellite data. J Vis Commun Image Represent 58:565-575. https://doi.org/10.1016/j.jvcir.2018.12.031

22. Lin Q, Liu EF, Zhang EL, Nath B, Bindler R, Liu J, Shen J (2021) Organic carbon burial in a large, deep alpine lake (southwest China) in response to changes in climate, land use and nutrient supply over the past similar to 100 years. CATENA 202:105240. https://doi.org/10.1016/j.catena.2021.105240

23. Lipczynska-Kochany E (2018) Effect of climate change on humic substances and associated impacts on the quality of surface water and groundwater: A review. Sci Total Environ 640:15481565. https://doi.org/10.1016/j.scitotenv.2018.05.376

24. Liu Y, Yue H (2017) Estimating the fluctuation of Lake Hulun, China, during 1975-2015 from satellite altimetry data. Environ Monit Assess 189:630. https://doi.org/10.1007/s10661-017-6346-z

25. Liu YY, Chen GJ, Meyer-Jacob C, Huang LP, Liu XL, Huang GC, Klamt AM, Smol JP (2021) Land-use and climate controls on aquatic carbon cycling and phototrophs in karst lakes of southwest China. Sci Total Environ 751:141738. https://doi.org/10.1016/j.scitotenv.2020.141738

26. Lozano-Garcia S, Torres-Rodriguez E, Ortega B, Vazquez G, Caballero M (2013) Ecosystem responses to climate and disturbances in western central Mexico during the late Pleistocene and Holocene. Palaeogeography Palaeoclimatology Palaeoecology 370:184-195. https://doi.org/10.1016/j.palaeo.2012.12.006

27. Lu WW, Yao X, Shao KQ, Zhang BH, Gao G (2019) Unraveling the sources and fluorescence compositions of dissolved and particulate organic matter (DOM and POM) in Lake Taihu, China. 
Environ Sci Pollut Res 26:4027-4040. https://doi.org/10.1007/s11356-018-3873-2

28. Luff R, Moll A (2004) Seasonal dynamics of the North Sea sediments using a three-dimensional coupled sediment-water model system. Cont Shelf Res 24:1099-1127.

https://doi.org/10.1016/j.csr.2004.03.010

29. Melenevskii VN, Leonova GA, Bobrov VA, Kashirtsev VA, Krivonogov SK (2015) Transformation of organic matter in the holocene sediments of Lake Ochki (South Baikal Region): Evidence from Pyrolysis Data. Geochem Int 53:903-921. https://doi.org/10.1134/s0016702915080054

30. Meyers PA (1994) Preservation of elemental and isotopic source identification of sedimentary organic matter. Chem Geol 114:289-302. https://doi.org/10.1016/0009-2541(94)90059-0

31. Meyers PA (1997) Organic geochemical proxies of paleoceanographic, paleolimnologic, and paleoclimatic processes. Org Geochem 27:213-250. https://doi.org/10.1016/S0146-6380(97)000491

32. Nie YG, Xu LQ, Liu XD, Emslie SD (2016) Radionuclides in ornithogenic sediments as evidence for recent warming in the Ross Sea region, Antarctica. Sci Total Environ 557:248-256. https://doi.org/10.1016/j.scitotenv.2016.03.046

33. Piotr K, Renata GR, Lilianna B (2018) An isotopic model for the origin of autochthonous organic matter contained in the bottom sediments of a reservoir. Int J Sedim Res 33:285-293. https://doi.org/10.1016/j.ijsrc.2017.10.002

34. Pu Y, Werne JP, Meyers PA, Zhang HC (2020) Organic matter geochemical signatures of sediments of Lake Ngoring (Qinghai-Tibetan Plateau): A record of environmental and climatic changes in the source area of the Yellow River for the last 1500 years. Palaeogeography Palaeoclimatology Palaeoecology 551:109729. https://doi.org/10.1016/j.palaeo.2020.109729

35. Qian JL, Wang SM, Xue B, Chen RS, Ke SZ (1997) A method of quantitative estimating terrestrial organic carbon in lake sedimentation research. Chin Sci Bull 42:1655-1658. https://doi.org/10.1360/csb1997-42-15-1655

36. Qiang MR, Chen FH, Zhang JW, Gao SY, Zhou AF (2005) Climatic changes documented by stable isotopes of sedimentary carbonate in Lake Sugan, northeastern Tibetan Plateau of China, since 2 kaBP. Chin Sci Bull 50:1930-1939. https://doi.org/10.1360/04wd0285

37. Razum I, Bajo P, Brunovic D, Ilijanic N, Hasan O, Roehl U, Miko MS, Miko S (2021) Past climate variations recorded in needle-like aragonites correlate with organic carbon burial efficiency as revealed by lake sediments in Croatia. Sci Rep 11:7568. https://doi.org/10.1038/s41598-021-871662

38. Rochelle-Newall EJ, Fisher TR (2002) Production of chromophoric dissolved organic matter fluorescence in marine and estuarine environments: an investigation into the role of phytoplankton. Mar Chem 77:7-21. https://doi.org/10.1016/S0304-4203(01)00072-X

39. Sobek S, Anderson NJ, Bernasconi SM, Del Sontro T (2014) Low organic carbon burial efficiency in arctic lake sediments. Journal of Geophysical Research: Biogeosciences 119:1231-1243. https://doi.org/10.1002/2014jg002612 
40. Sun WW, Zhang EL, Jones RT, Liu EF, Shen J (2016) Biogeochemical processes and response to climate change recorded in the isotopes of lacustrine organic matter, southeastern Qinghai-Tibetan Plateau, China. Palaeogeography, Palaeoclimatology, Palaeoecology 453. 93-100. https://doi.org/10.1016/j.palaeo.2016.04.013

41. Wang QL, Xie YY, Mei H (2003) The characteristics of compositions of the organic matter $\delta^{13} \mathrm{C}$ in lake sediments and its paleoclimatic environmental significance. Safety and Environmental Engineering 10:17-21. https://doi.org/10.3969/j.issn.1671-1556.2003.04.005

42. Wang WW, Chen JY, Jiang X, Li H, Wang SH (2021a) Release effect of surface sediment organic matters in Lake Hulun. Res Environ Sci 34:812-823. https://doi.org/10.13198/j.issn.10016929.2021 .02 .03

43. Wang WW, Wang SH, Jiang X, Zheng BH, Zhao L, Zhang B, Chen JY (2018) Differences in fluorescence characteristics and bioavailability of water-soluble organic matter (WSOM) in sediments and suspended solids in Lihu Lake, China. Environ Sci Pollut Res 25:12648-12662. https://doi.org/10.1007/s11356-017-1127-3

44. Wang WW, Wang SH, Jiang X, Chen JY, Zheng BH (2021b) Occurrence characteristics and sources analysis of sediment organic matter of Lake Hulun by multiple methods. Res Environ Sci 34:305318. https://doi.org/10.13198/j.issn.1001-6929.2020.08.06

45. Xiao QT, Xu XF, Duan HT, Qi TC, Qin BQ, Lee XH, Hu ZH, Wang W, Xiao W, Zhang M (2020) Eutrophic Lake Taihu as a significant $\mathrm{CO}_{2}$ source during 2000-2015. Water Res 170:115331. https://doi.org/10.1016/j.watres.2019.115331

46. Yi GH, Zhang TB (2015) Delayed response of lake area change to climate change in Siling Co Lake, Tibetan Plateau, from 2003 to 2013. Int J Environ Res Public Health 12:13886-13900. https://doi.org/10.3390/ijerph121113886

47. Zhang B, Wang SH, Jinag X, Huang XF, Wang WW (2017) Sequential extractions and fluorescene spectroscopy characterization of organic matter in the Lake Sediment. Acta Sci Circum 37:28782888. https://doi.org/10.13671/j.hjkxxb.2017.0023

48. Zhang FJ, Xue B, Yao SC, Gui ZF (2018a) Organic carbon burial from multi-core records in Hulun Lake, the largest lake in northern China. Quatern Int 475:80-90.

https://doi.org/10.1016/j.quaint.2017.12.005

49. Zhang FJ, Xue B, Yao SC (2018b) Organic carbon burial and its driving mechanism in the sediment of Lake Hulun, north-eastern Inner Mongolia, since the mid-Holocene. Journal of Lake Sciences 30:234-244. https://doi.org/10.18307/2018.0123

50. Zhang L, Sun QX, You Y, Zhang K, Gao CD, Peng YZ (2021) Compositional and structural characteristics of dissolved organic matter in overlying water of the Chaobai River and its environment significance. Environ Sci Pollut Res. https://doi.org/10.1007/s11356-021-14929-9

51. Zhao HY, Wu LJ, Hao WJ (2008) Influences of climate change to ecological and environmental evolvement in the Hulun Lake wetland and its surrounding areas. Acta Ecol Sin 28:1064-1071. https://doi.org/10.3321/j.issn:1000-0933.2008.03.020 
52. Zhao WW, Chen CZ, Jiang QF, Ji M, Zhen JN, Yang YF, Ning DL, Li XZ, Shen J (2021) Holocene hydroclimate in the source region of the Yellow River: A new sediment record from Lake Gyaring, NE Tibetan Plateau. J Asian Earth Sci 205:104601. https://doi.org/10.1016/j.jseaes.2020.104601

\section{Figures}

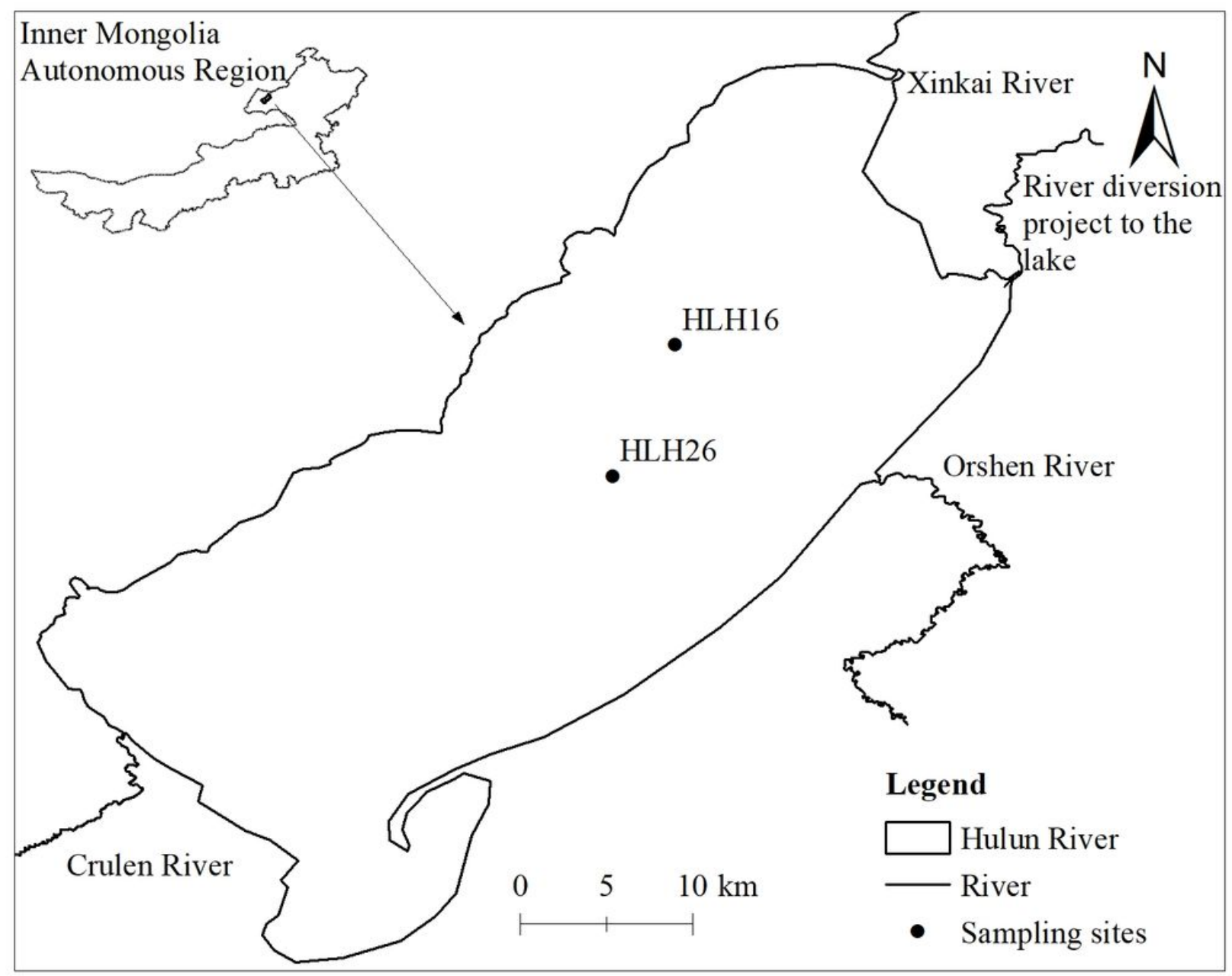

Figure 1

Sampling map of Hulun Lake. 


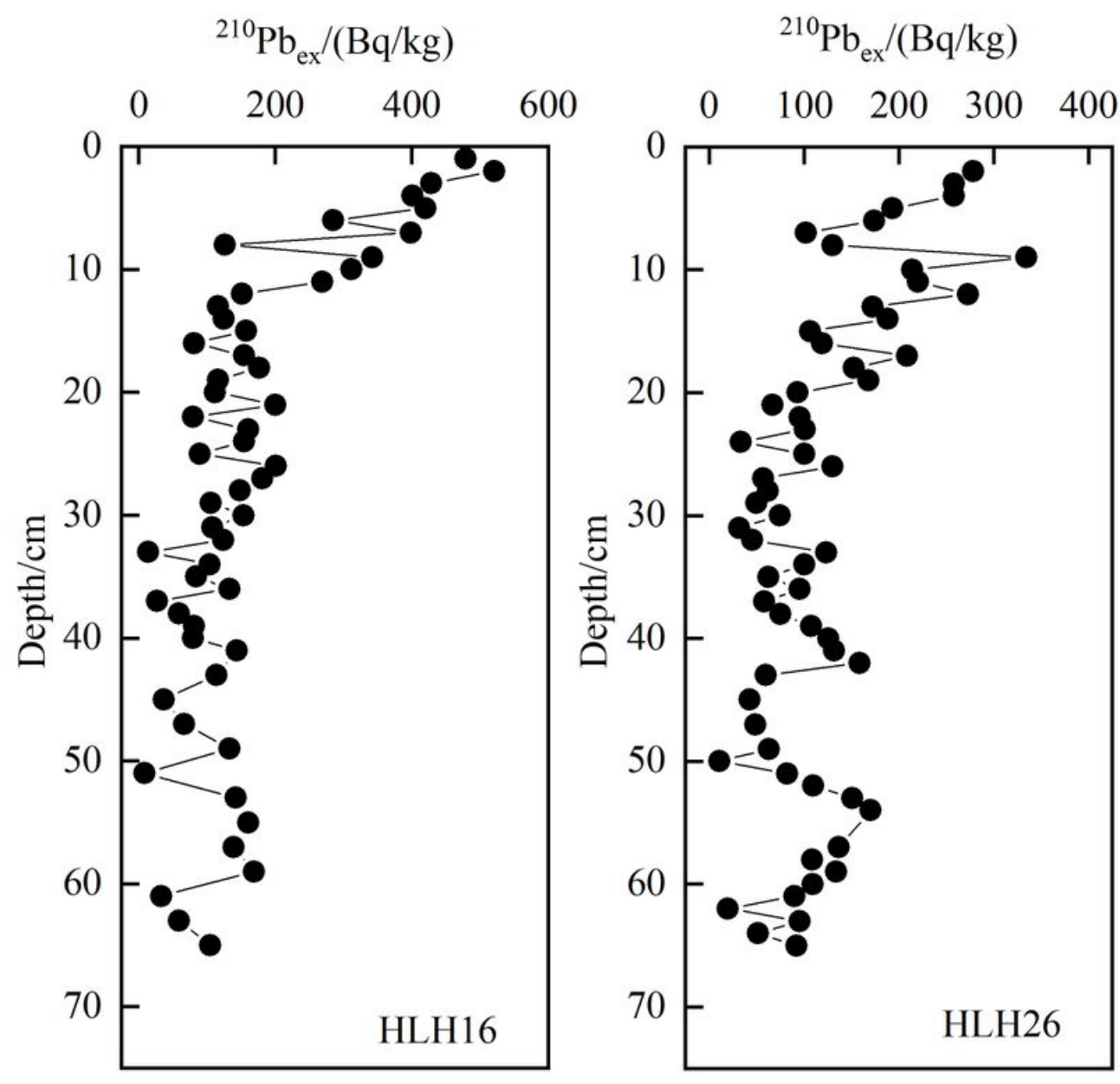

Figure 2

Vertical distributions of ${ }^{210} \mathrm{~Pb}_{\mathrm{ex}}$ in sediments of Hulun Lake 

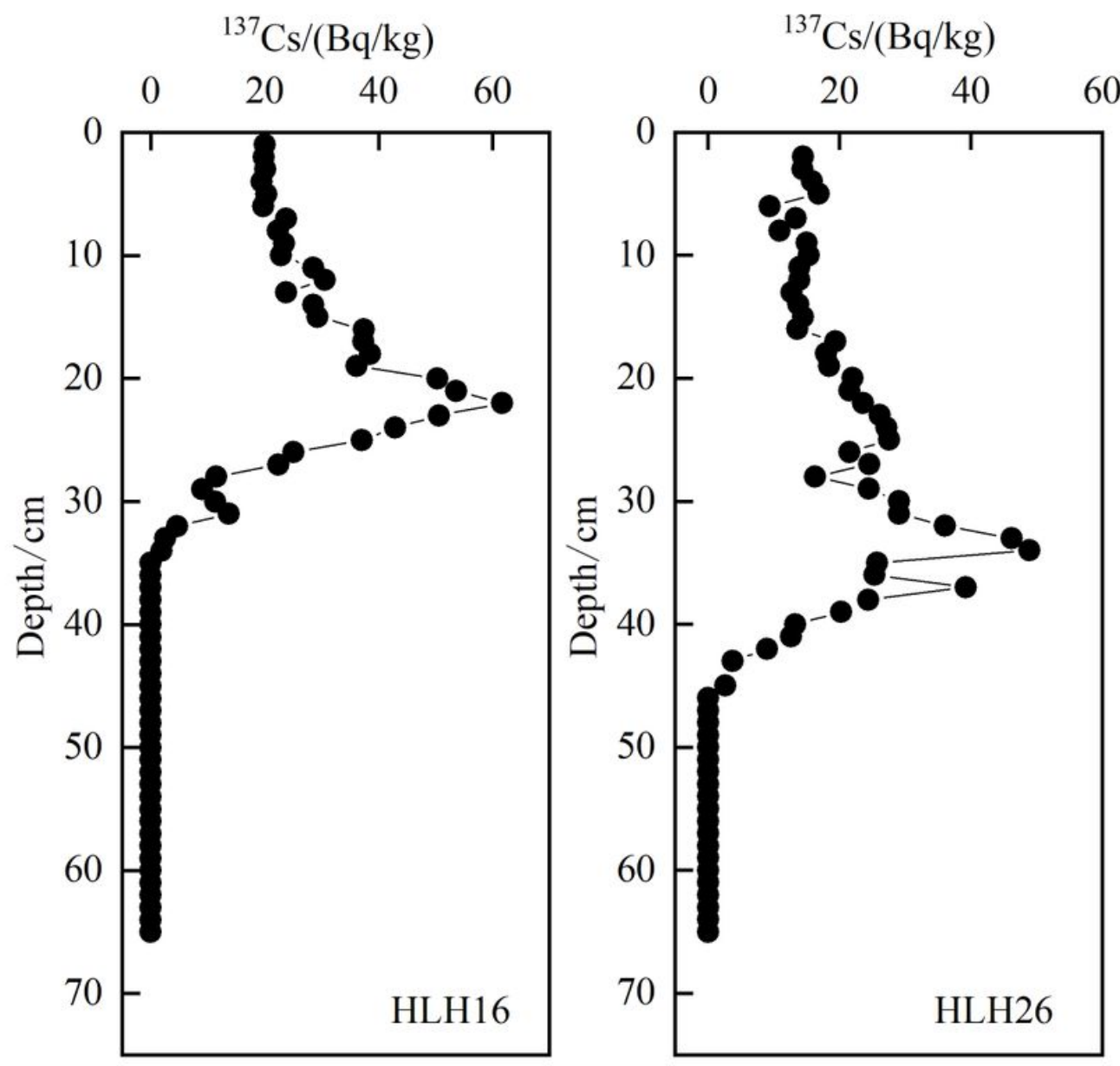

Figure 3

Vertical distributions of ${ }^{137} \mathrm{Cs}$ in sediments of Hulun Lake 


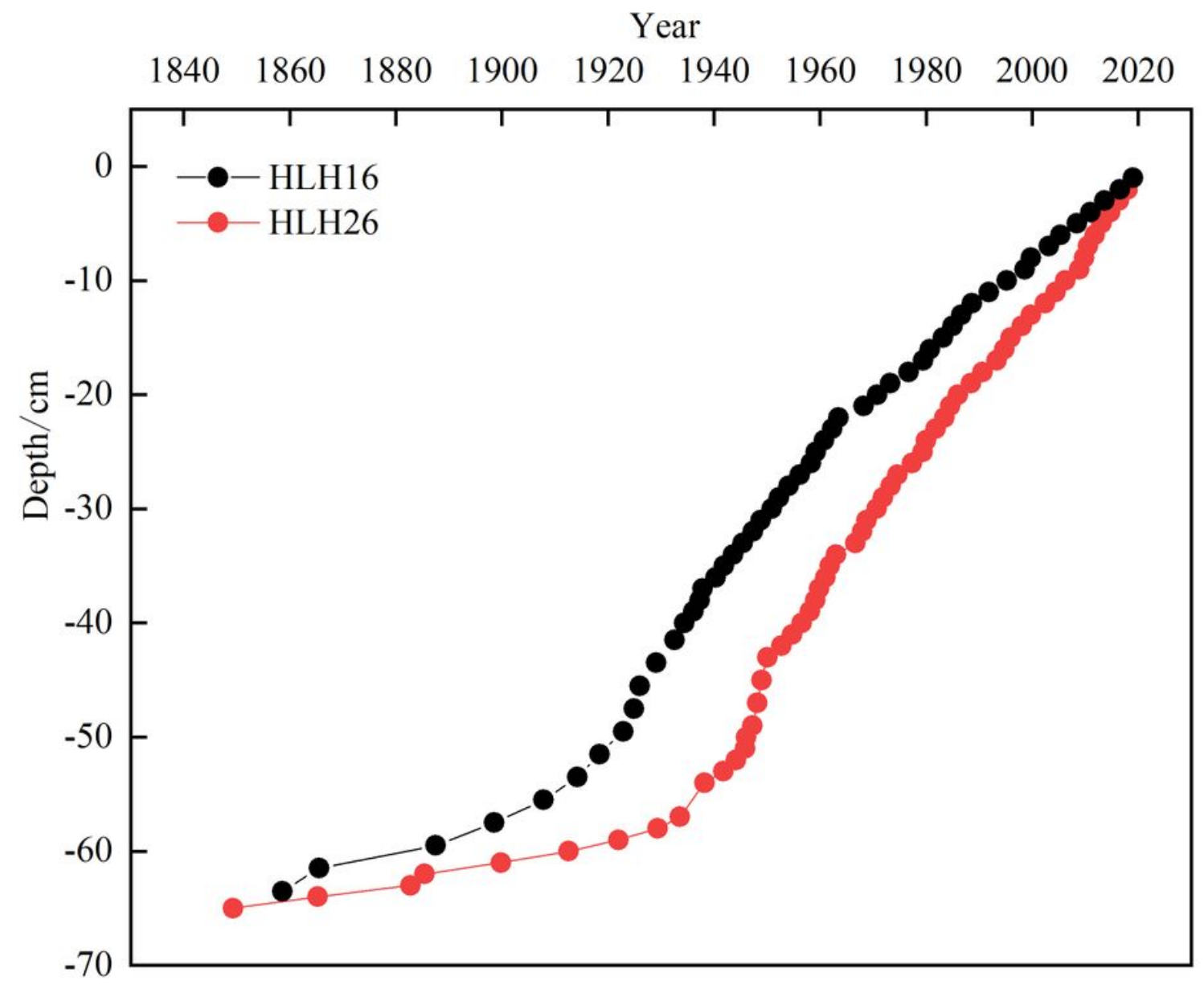

Figure 4

Depth-chronology model of the sediment cores in Hulun Lake 

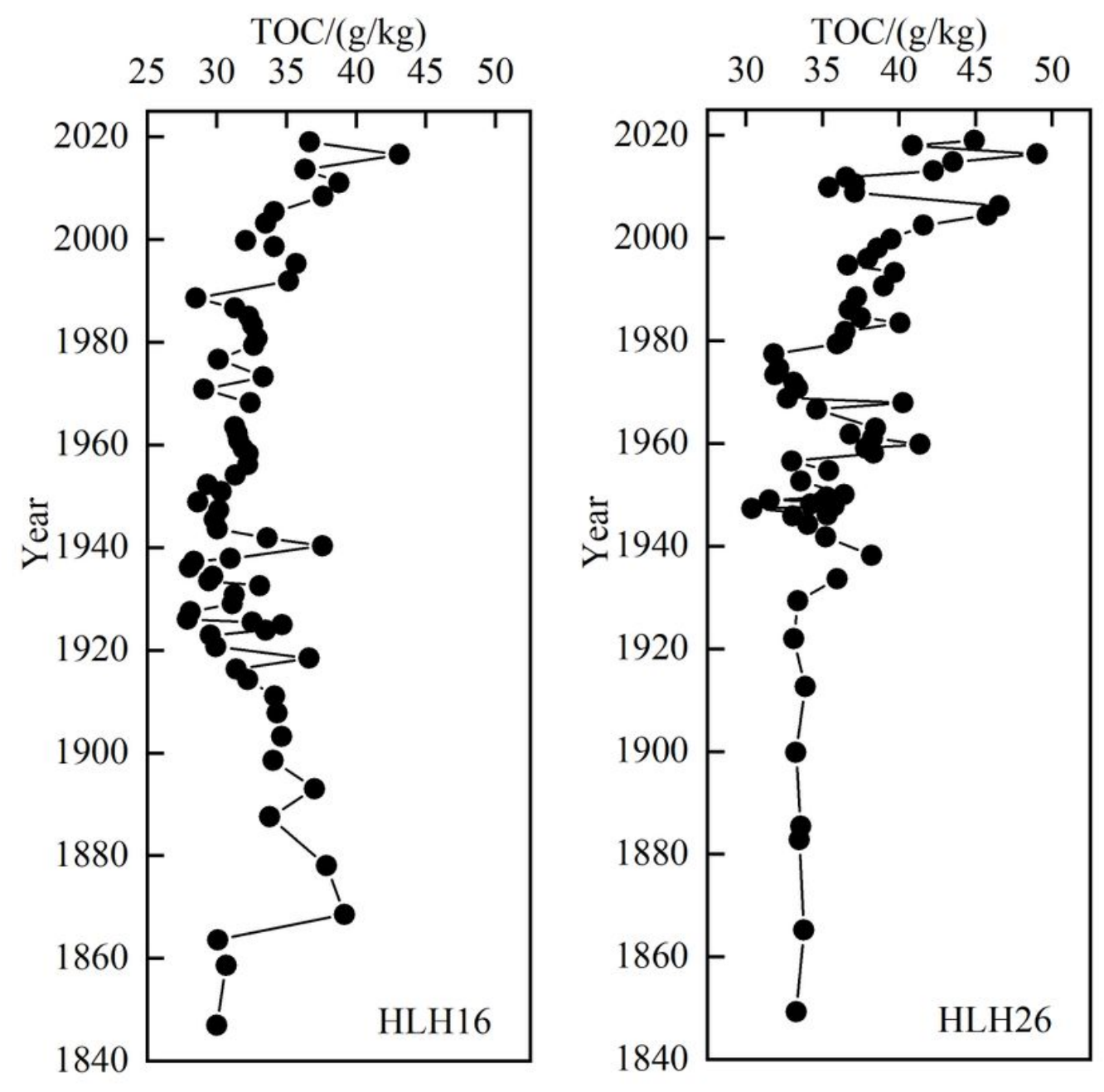

Figure 5

Historical changes of TOC contents in sediment cores of Lake Hulun 

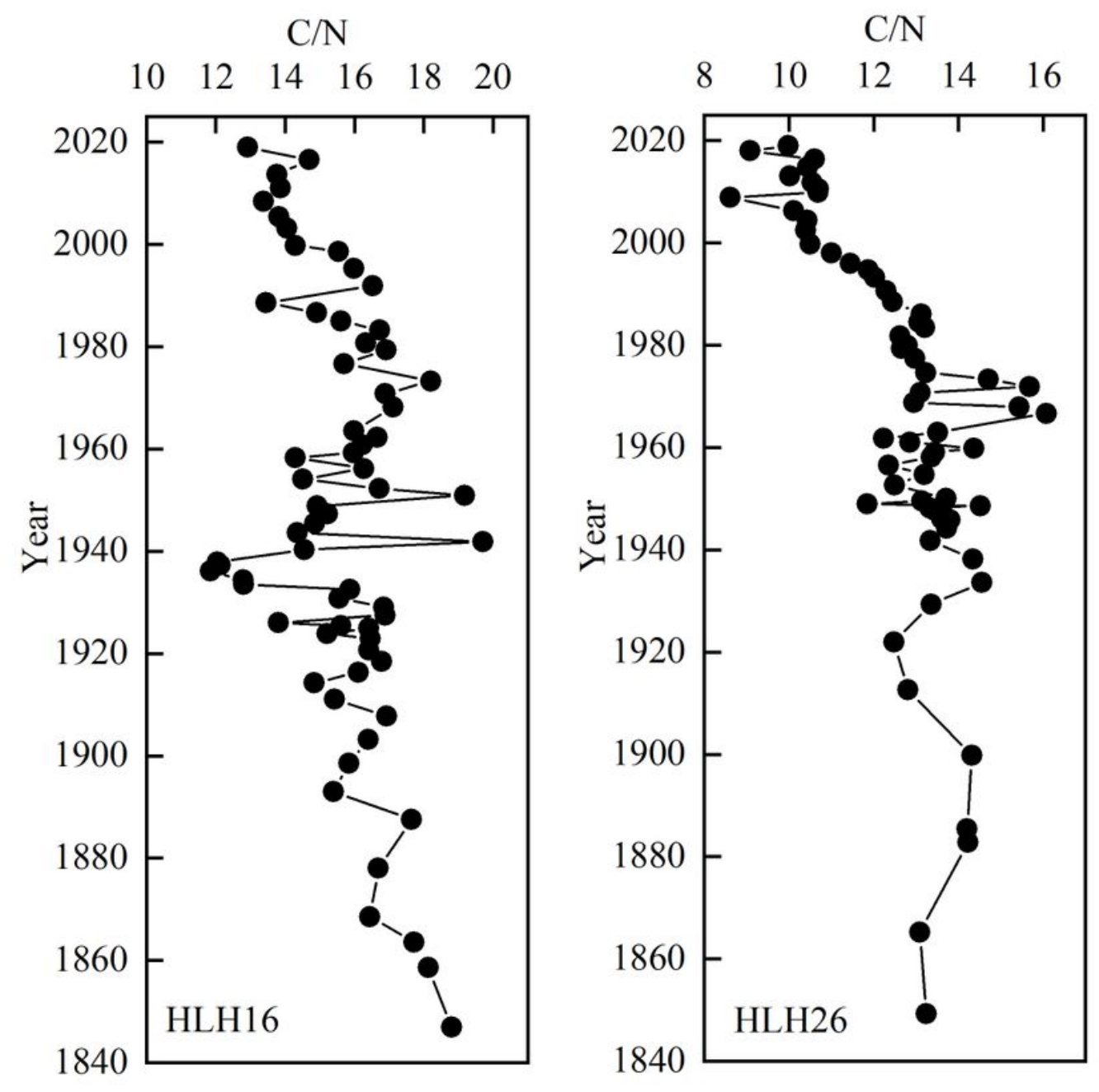

Figure 6

Historical changes of $\mathrm{C} / \mathrm{N}$ values in sediment cores of Hulun Lake

Figure 7

Historical variations of $\delta^{13} \mathrm{C}$ in sediment cores of Hulun Lake

Figure 8 
Historical changes of fluorescence intensity (FI) of protein-like WEOM component in sediment cores of Hulun Lake

Figure 9
(a) Calculated by $\mathrm{C} / \mathrm{N}$
(b) Calculated by $\delta^{13} \mathrm{C}$

Changes of relative contributions of terrestrial and autogenous source of SOM in Lake Hulun

Figure 10

Historical changes of annual temperature, precipitation and evaporation of Hulun Lake basin 